\title{
Occurrence of the physonect siphonophore Apolemia uvaria off Plymouth and in south-west England
}

\author{
KEITH HISCOCK ${ }^{1}$, GILLIAN M. MAPSTONE ${ }^{2}$, DAVID V.P. CONWAY ${ }^{1}$ AND NICHOLAS HALLIDAY ${ }^{1}$ \\ ${ }^{1}$ Marine Biological Association, The Laboratory, Citadel Hill, Plymouth PL1 2PB, UK, ${ }^{2}$ Natural History Museum, Cromwell Road, \\ London $\mathrm{SW}_{7}$ 5BD, UK
}

\begin{abstract}
In September 2007, observations were made of a siphonophore in surface waters and near to the seabed by sea users off south Devon and south-east Cornwall. The same siphonophore was also recorded from regular samples collected offshore of Plymouth. The species is identified as Apolemia uvaria, which had not previously been recorded off Plymouth. It was sampled until March 2008 and re-appeared, in smaller numbers, in autumn 2008 until February 2009 but was not reliably reported in autumn 2009 (to end of October). The occurrence is unlikely to be due to sea warming, but more likely some variation in oceanic currents, possibly influxes of Atlantic water.
\end{abstract}

Keywords: Apolemia uvaria, siphonophore, sea warming, oceanic currents

Submitted 4 November 2009; accepted 18 January 2010

Published records of the occurrence of the physonect siphonophore Apolemia uvaria (Lesueur, 1815) in British waters are sporadic and widely distributed, from the Celtic Sea and the south-west continental shelf edge to the northern North Sea (Fraser, 1961; Kirkpatrick \& Pugh, 1984; Mapstone, 2003). The species has not previously been recorded from Cornish waters in the Environmental Records Centre for Cornwall and the Isles of Scilly (ERCCIS) database (P. Gainey, personal communication), and is not mentioned in either the Plymouth Marine Fauna (Marine Biological Association, 1957) or in correspondence about unusual sightings held by the Marine Biological Association (MBA). Although the first MBA records are from 2007, $A$. uvaria has been seen regularly in the western part of south Cornwall for many years, with 2003 and 2008 being years of particularly numerous sightings (D. Roberts, Kennack Diving, personal communication). Offshore of Falmouth, A. uvaria has been seen since 2004, particularly during autumn and winter months (M. Tuck, personal communication). Furthermore, boatmen in the Isles of Scilly indicated, late in 2007, sightings of A. uvaria over many years (A. Gall, Isles of Scilly Wildlife Trust, personal communication). Sampling off Plymouth at the long-term monitoring stations $\mathrm{L}_{4}, \mathrm{~L}_{5}$ and $\mathrm{E}_{1}$ has predominantly caught $A$. uvaria in coarse mesh plankton tows taken throughout the water column. Table 1 summarizes observations since 2007 made by or forwarded to the authors and which are considered reliable (they were sampled or good quality images were taken). In summer 2009, we received several records including some images of siphonophores from the Isles of Scilly to off Plymouth but they were almost certainly all of Agalma elegans.

Corresponding author:

K. Hiscock

Email: khis@mba.ac.uk
Apolemia uvaria is prone to fragmentation (Mapstone, 2009, p. 21) and the records in Table 1 probably represent fragments rather than complete colonies. Physonect siphonophores, often called 'string jellies', are long, complex polymorphic cnidarians. They are divided into two principal parts: a nectosome comprising a small float (pneumatophore) and numerous swimming bells (nectophores) for propulsion, and an attached siphosome of serially repeated units (cormidia) for feeding and reproduction. Although whole colonies have been collected from the Mediterranean Sea, there are no reliable records yet for the nectosome portion of A. uvaria from the Atlantic Ocean (Mapstone 2003, p. 194). This nectosome portion often breaks free from the siphosome in A. uvaria and swims away independently, leaving lengths of siphosomal stem that drift around in the water for some time, but cannot swim.

Although apolemiids are most easily identified from their nectosomal nectophores, the siphosomal stem fragments shown in Figures $1-3$ can be positively identified as $A$. uvaria for several reasons, which are worth describing here to facilitate future identifications. Each fragment is long (Figure 1) and consists of groups of cormidia separated by lengths of bare stem (internodes). Cormidia of A. uvaria are distinctive because in addition to one or more mouths (gastrozooids), they contain two types of palpons (white and red; Figures 3-4), whereas in other apolemiid species only one palpon type is present. In addition, each cormidium bears several bracts, and these help to buoy up the heavy stem as well as protect the mouths and palpons from damage. In $A$. uvaria the canals of these bracts have a characteristic tip that fuses with the lower surface of the bract and then extend a short distance beyond this point (Figure 4); in the bracts of other apolemiids there is no such extension (see Mapstone 2003, figure 13a-f). Also, in the present siphosomal stem lengths of $A$. uvaria (Figures 2-4) no reproductive structures (gonophores and gonodendra) are observed, which is to 
Table 1. Sightings of Apolemia uvaria reported in 2007 and 2008.

\begin{tabular}{|c|c|c|c|c|}
\hline Date of observation & Location & $\begin{array}{l}\text { Position (where } \\
\text { known) }\end{array}$ & Notes & Observer \\
\hline $06 / 09 / 2007$ & St Agnes, Isles of Scilly & $\begin{array}{l}49^{\circ} 53 \cdot 55^{\prime} \mathrm{N} \\
6^{\circ} 20.20^{\prime} \mathrm{W}\end{array}$ & String about $2 \mathrm{~m}$ long off the rocky shore & P. Phillips \\
\hline $13 / 10 / 2007$ & Wreck of 'Rosehill' & $\begin{array}{l}50^{\circ} 19.80^{\prime} \mathrm{N} \\
4^{\circ} 18.53^{\prime} \mathrm{W}\end{array}$ & One string & K. Hiscock \\
\hline $03 / 11 / 2007$ & Hilsea Point Rock & $50^{\circ} 17.32^{\prime} \mathrm{N}_{4}^{\circ} 2.70^{\prime} \mathrm{W}$ & $\begin{array}{l}\text { String about } 2 \mathrm{~m} \text { long over the rocky } \\
\text { seabed }\end{array}$ & K. Hiscock \\
\hline $21 / 11 / 2007$ & Tean Sound, Isles of Scilly & $\begin{array}{l}49^{\circ} 57.95^{\prime} \mathrm{N} \\
6^{\circ} 18.34^{\prime} \mathrm{W}\end{array}$ & $\begin{array}{l}\text { About } 15 \text { separate strings. 'Still seeing } \\
\text { many around St Martin's and St } \\
\text { Mary's' }\end{array}$ & T. Allsop \\
\hline $23 / 12 / 2007(\mathrm{ca})$ & $\begin{array}{l}\sim 25 \text { miles south-east of } \\
\quad \text { Falmouth }\end{array}$ & $49^{\circ} 44^{\prime} \mathrm{N} 4^{\circ} 47^{\prime} \mathrm{W}$ & $\begin{array}{l}\text { Near-surface. From about } 5 \mathrm{~cm} \text { to } 1 \mathrm{~m} \text { in } \\
\text { length }\end{array}$ & M. Tuck \\
\hline $23 / 11 / 2007$ & Hand Deeps & $\begin{array}{l}50^{\circ} 12.42^{\prime} \mathrm{N} \\
4^{\circ} 20.44^{\prime} \mathrm{W}\end{array}$ & String about $30 \mathrm{~cm}$ long at the surface & K. Hiscock \\
\hline $30 / 12 / 2007$ & Hand Deeps & $\begin{array}{l}50^{\circ} 12.42^{\prime} \mathrm{N} \\
4^{\circ} 20.44^{\prime} \mathrm{W}\end{array}$ & $\begin{array}{l}\text { Two seen at } 38 \mathrm{~m} \text { depth over rocky seabed } \\
\text { and near the surface }\end{array}$ & K. Hiscock \\
\hline Early 08/2008 & 'Offshore' Plymouth & & $\begin{array}{l}\text { Possibly present over seabed at } 70 \mathrm{~m} \\
\text { depth }\end{array}$ & A. Boxall \\
\hline End $08 / 2008$ & ‘Offshore' Plymouth & & & A. Boxall \\
\hline $13 / 09 / 2008$ & Off Cape Cornwall & & Three strings & $\begin{array}{l}\text { Penzance Dive Club } \\
\text { newsletter }\end{array}$ \\
\hline $14 / 09 / 2008$ & Whitsand Bay & $\begin{array}{l}50^{\circ} 19.01^{\prime} \mathrm{N} \\
4^{\circ} 15.55^{\prime} \mathrm{W}\end{array}$ & $\begin{array}{l}\text { Mainly short lengths, one about } 1.2 \mathrm{~m} \\
\text { long, near to drift weed at surface }\end{array}$ & N. Hope \\
\hline $\begin{array}{l}11 / 09 / 2007 \text { to } 01 / 11 / \\
2007 \text { and } 03 / 06 / \\
2008 \text { to } 27 / 01 / 2009\end{array}$ & $\begin{array}{l}\text { Station } \mathrm{E}_{1} \\
\text { Station } \mathrm{L}_{5}\end{array}$ & $\begin{array}{l}50^{\circ} 02^{\prime} \mathrm{N} 04^{\circ} 22^{\prime} \mathrm{W} \\
50^{\circ} 11^{\prime} \mathrm{N} 04^{\circ} 18^{\prime} \mathrm{W}\end{array}$ & Short lengths in plankton samples & N. Halliday \\
\hline $\begin{array}{l}28 / 09 / 2007 \text { to } 05 / 03 / \\
2008 \text { and } 20 / 08 / \\
2008 \text { to } 23 / 02 / 2009\end{array}$ & Station $\mathrm{L}_{4}$ & $50^{\circ} 15^{\prime} \mathrm{N} 04^{\circ} 13^{\prime} \mathrm{W}$ & Short lengths in plankton samples & $\begin{array}{l}\text { D. Conway and } \\
\text { N. Halliday }\end{array}$ \\
\hline $26 / 09 / 2008$ & Wreck of the 'Maine' & $\begin{array}{l}50^{\circ} 12.85^{\prime} \mathrm{N} \\
3^{\circ} 51.01^{\prime} \mathrm{W}\end{array}$ & Identified from image & D. Walker \\
\hline $27 / 09 / 2008$ & Eddystone & $\begin{array}{l}50^{\circ} 10.81^{\prime} \mathrm{N} \\
4^{\circ} 16.00^{\prime} \mathrm{W}\end{array}$ & $\begin{array}{l}\text { Two at } 15 \mathrm{~m} \text { depth near seabed, one near } \\
\text { surface }\end{array}$ & K. Hiscock \\
\hline $12 / 10 / 2008$ & Wreck of the 'Maine' & $\begin{array}{l}50^{\circ} 12.85^{\prime} \mathrm{N} \\
3^{\circ} 51.01^{\prime} \mathrm{W}\end{array}$ & One, $\sim 50 \mathrm{~cm}$ long & A. Pollard \\
\hline $22 / 12 / 2008$ & $\begin{array}{l}\text { Distant }(\sim 60 \mathrm{~km}) \\
\text { offshore Falmouth Bay }\end{array}$ & $\begin{array}{l}49^{\circ} 30^{\prime} \mathrm{N} 4^{\circ} 50^{\prime} \mathrm{W} \text { to } \\
49^{\circ} 30^{\prime} \mathrm{N} 5^{\circ} 15^{\prime} \mathrm{W}\end{array}$ & $\begin{array}{l}\text { Surface waters 'thick with them'. Great } \\
\text { majority small }(\sim 5 \mathrm{~cm}) \text { and several } \\
\text { long chains }\end{array}$ & M. Tuck \\
\hline
\end{tabular}

be expected because in A. uvaria gonophores only form at the extreme posterior (distal) end of the stem (Mapstone 2003, p. 200). In at least one other apolemiid species, gonophores are known to be distributed along most of the siphosome (Mapstone, personal observation).

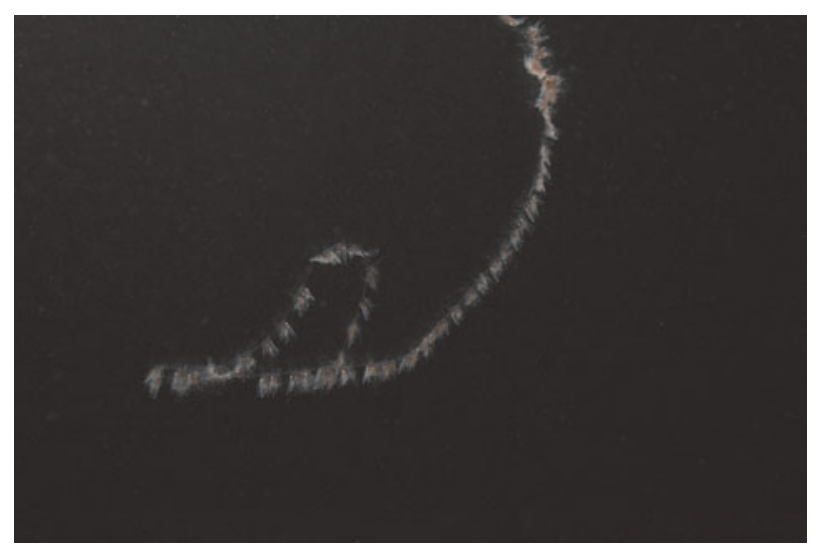

Fig. 1. Siphosomal fragment of Apolemia uvaria bearing many cormidia. Hilsea Point Rock, South Devon. Length of stem fragment $\sim 1-2 \mathrm{~m}$.
In whole unfragmented apolemiid colonies, many elongate tentacles emerge from the siphosomal stem, one from each gastrozooid or palpon. When feeding these hang down some distance (Mapstone 2003, figure 14), exposing a row of stinging cells (nematocysts), which inflict a painful and often lethal

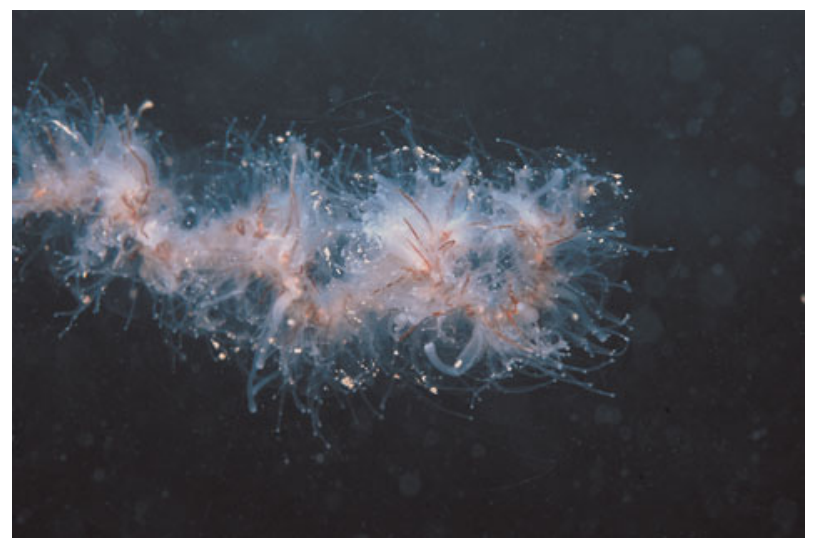

Fig. 2. Part of a siphosomal fragment of Apolemia uvaria showing several cormidia with gastrozooids, many translucent palpons and some shorter red palpons. Hand Deeps, offshore south Cornwall. Diameter of cormidial clusters $<5 \mathrm{~mm}$. 


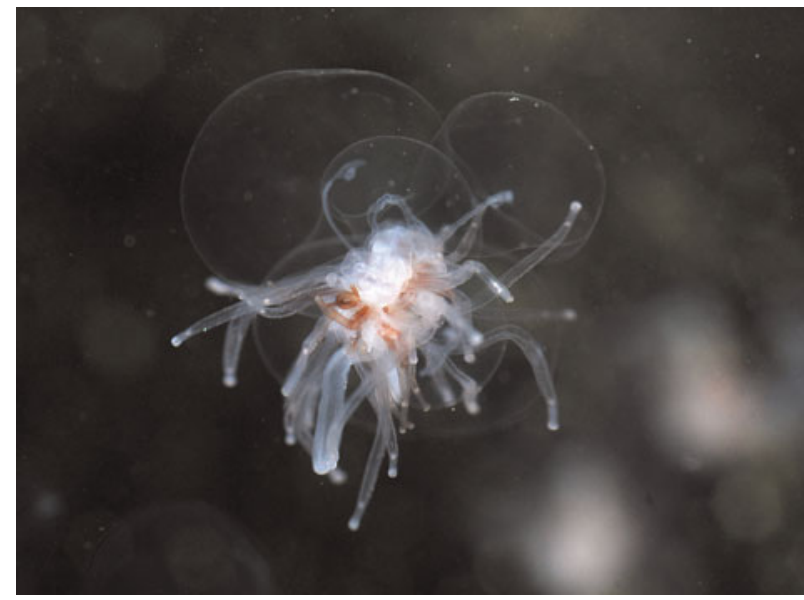

Fig. 3. Detached single cormidium of Apolemia uvaria (see Figure 4 below for interpretive drawing) Stoke Point, South Devon. Diameter of cormidial cluster $<5 \mathrm{~mm}$.

sting to the prey. In the single cormidium shown in Figure 3, the tentacles are withdrawn between the palpons (so not visible), but in other cormidia (images available from the authors) tentacles like that illustrated in Figure ${ }_{4} \mathrm{C}$ are visible.
Occurrences of A. uvaria become particularly newsworthy when the species causes mortality in farmed salmon, as happened in south-west Ireland, Shetland and Norway in the late 1990s. In autumn 1998, 'string jellies' were present in samples from the Sea of the Hebrides and The Minch (S. Hay, personal communication). Fraser (1961) observed that A. uvaria had become established in the northern North Sea and was not limited to the Mediterranean as previously thought.

The occurrence of Apolemia uvaria as far north as Norway (Båmstedt et al., 1998) and, at least from the 1960s in the northern North Sea, makes it unlikely that seawater warming is a reason for its recent presence off Plymouth. It seems more probable that some variation in ocean currents or upwelling of deeper waters has caused more specimens to be brought into British waters, as suggested by Båmstedt et al. (1998) for the Norwegian increase.

\section{ACKNDWLEDGEMENTS}

Thanks to all of the observers who have provided records and especially to Michael Tuck for keeping us regularly informed of occurrences out of Falmouth; also to Barry Mapstone for Figure 4 .

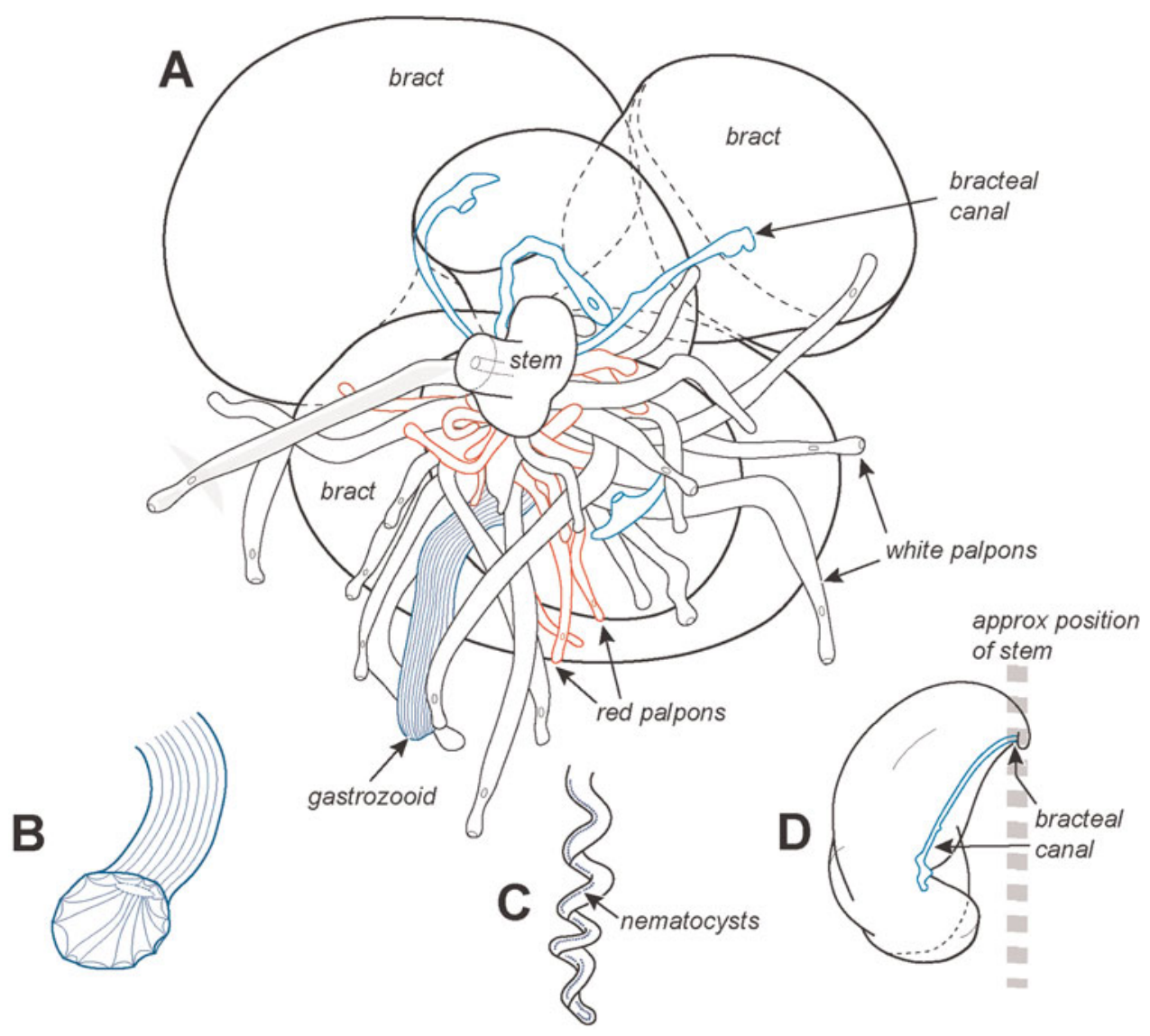

Fig. 4. Schematic interpretation of Figure 3. (A) A cormidium of Apolemia uvaria with 5 bracts attached to the central siphosomal stem with stem canal (out of page and to left), a gastrozooid, and many white and red palpons. Each bract has a bracteal canal (blue); the muscular gastrozooid ingests prey and the thinner white and red palpons assist with digestion and waste removal; (B) sketch of gastrozooid (mouth) in open feeding mode; (C) example of coiled tentacle with simple row of nematocysts (not shown in A above); (D) side view of jelly-filled bract showing approximate life position of stem. Diameter of cormidial cluster in Figure $4 \mathrm{~A}<5 \mathrm{~mm}$. 


\section{REFERENCES}

Båmstedt U., Fosså J.H., Martinussen M.B. and Fosshagen A. (1998) Mass occurrence of the physonect siphonophore Apolemia uvaria (Lesueur) in Norwegian waters. Sarsia 83, 79-85.

Fraser J.H. (1961) The oceanic and bathypelagic plankton of the northeast Atlantic. Marine Research 4, 1-48.

Kirkpatrick P.A. and Pugh P.R. (1984) Siphonophores and velellids. Synopsis of the British Fauna, Number 29. London: The Linnean Society of London and The Estuarine and Brackish-Water Sciences Association, E.J. Brill.

Mapstone G.M. (2003) Redescriptions of two physonect siphonophores, Apolemia uvaria (Lesueur, 1815) and Tottonia contorta Margulis, 1976 , with comments on a third species Ramosia vitiazi Stepanjants,
1967 (Cnidaria: Hydrozoa: Apolemiidae). Systematics and Biodiversity 1, 181-212.

Mapstone G.M. (2009) Siphonophora (Cnidaria: Hydrozoa) of Canadian Pacific waters. Ottawa: NRC Press, 302 pp.

and

Marine Biological Association (1957) Plymouth marine fauna. Plymouth: The Marine Biological Association of the United Kingdom.

\section{Correspondence should be addressed to:}

K. Hiscock

Marine Biological Association of the United Kingdom The Laboratory, Citadel Hill, Plymouth PL1 2PB, UK email: khis@mba.ac.uk 